\title{
NOTES
}

\section{Photobacterium logei sp. nov., nom. rev.; Beneckea nereida sp. nov., nom. rev.; and Beneckea gazogenes sp. nov., nom. rev.}

\author{
C. S. HARWOOD, ${ }^{1}$ S. S. BANG, ${ }^{2}$ P. BAUMANN,${ }^{2}$ aND K. H. NEALSON ${ }^{3}$
}

Department of Microbiology, University of Massachusetts, Amherst, Massachusetts 01003 ${ }^{1}$; Department of Bacteriology, University of California, Davis, California $95616^{2}$; and Scripps Institution of Oceanography, La Jolla, California $92093^{3}$

The names Photobacterium logei Bang et al., Beneckea nereida Baumann et al., and Beneckea gazogenes Harwood were not included in the recently published Approved Lists of Bacterial Names and hence have no standing in bacteriological nomenclature. However, these names are here revived for the same organisms with which they were originally associated and, by this action, now have valid status. According to the current rules of nomenclature, the authors of this present proposal, not the original authors, are to be cited as the authors of these names.

The bacterial names tabulated below (Table 1) were published before 1 January 1980 , but they became invalid by not having been announced in the International Journal of Systematic Bacteriology in accord with Rule 27 of the Bacteriological Code (4). Therefore, these names were not included in the recently published Approved Lists of Bacterial Names (5). The purpose of this communication is to effect the revival of these names and thus to give them valid status. According to Provisional Rule B1 of the Bacteriological Code (4), the authors of this present proposal, not the original authors of the names, are to be cited as the authors of these names.

\section{LITERATURE CITED}

1. Bang, S. S., P. Baumann, and K. H. Nealson. 1978 Phenotypic characterization of Photobacterium logei (sp. nov.), a species related to $P$. fischeri. Curr. Microbiol. 1:285-288.

2. Baumann, P., L. Baumann, and M. Mandel. 1971 Taxonomy of marine bacteria: the genus Beneckea. J. Bacteriol. 107:268-294.

3. Harwood, C. S. 1978. Beneckea gazogenes sp. nov., a red, facultatively anaerobic marine bacterium. Curr. Microbiol. 1:233-238.

4. Lapage, S. P., P. H. A. Sneath, E. F. Lessel, V. B. D. Skerman, H. P. R. Seeliger, and W. A. Clark. 1975. International code of nomenclature of bacteria. American Society for Microbiology, Washington, D.C.

5. Skerman, V. B. D., V. McGowan, and P. H. A. Sneath (ed). 1980. Approved lists of bacterial names. Int. J. Syst. Bacteriol. 30:225-420.

TABLE 1. List of bacterial names to be revived and accorded valid publication status

\begin{tabular}{llccc}
\hline \multicolumn{1}{c}{ Name } & Proposed as: & $\begin{array}{c}\text { Authors of original publi- } \\
\text { cation }\end{array}$ & $\begin{array}{c}\text { Literature cita- } \\
\text { tion to previous } \\
\text { description and } \\
\text { proposal of name }\end{array}$ & Nomenclatural type ${ }^{a}$ \\
\hline Photobacterium logei & New species & Bang et al. & 1 & $\begin{array}{c}\text { Strain 584 } \\
(=\text { ATCC 29985) } \\
\text { Beneckea nereida }\end{array}$ \\
Beneckea gazogenes & New species & Baumann et al. & 2 & $\begin{array}{c}\text { Strain 80 } \\
(=\text { ATCC 25917) } \\
\text { Strain PB1 } \\
(=\text { ATCC 2998) }\end{array}$ \\
\hline
\end{tabular}

\footnotetext{
${ }^{a}$ ATCC, American Type Culture Collection, Rockville, Md.
} 